\title{
Polyhydroxybutyrate Production using Agro-industrial Residue as Substrate by Bacillus sphaericus NCIM 5149
}

\author{
Nisha V. Ramadas ${ }^{1}$, Sudheer Kumar Singh ${ }^{1}$, Carlos Ricardo Soccol ${ }^{2}$ and Ashok Pandey ${ }^{1 *}$ \\ ${ }^{1}$ Biotechnology Division; National Institute for Interdisciplinary Science and Technology; Trivandrum-695 019; \\ Kerala - India. ${ }^{2}$ Divisão de Biotecnologia; Departamento de Engenharia Química; Universidade Federal do \\ Paraná; 81531-970; Curitiba - PR - Brasil
}

\begin{abstract}
The aim of this work was to study the production of polyhydroxybutyrate (PHB) using agro-industrial residues as the carbon source. Seven substrates, viz., wheat bran, potato starch, sesame oil cake, groundnut oil cake, cassava powder, jackfruit seed powder and corn flour were hydrolyzed using commercial enzymes and the hydrolyzates assessed for selecting the best substrate for PHB production. Jackfruit seed powder gave the maximum production of PHB under submerged fermentation using Bacillus sphaericus (19\%) at the initial pH of 7.5.
\end{abstract}

Key words: Bacillus sphaericus, Polyhydroxybutyrate, Jackfruit seed powder

\section{INTRODUCTION}

The history of plastic begins from 1862 by Alexander Parkes. The superior characters such as durability, strengths, shape and moldable oblige mankind incredibly depend on plastic for their daily life. According to the statistics in 2000, the annual consumption of plastics in India was about to reach $4 \mathrm{~kg} /$ person/year, and that of world average of $24.5 \mathrm{~kg}$. By 2010, global consumption of plastics is expected to reach up $258 \mathrm{mt} /$ year from 180mt/year (Association of German Plastics Manufacturers, 2001). Since these plastics have high molecular weight and tightly bonded together, these are not degradable, which makes their disposal difficult and inversely leads to negative impact on the environment. Thus, the concept of biodegradable plastic came as a solution for this problem, which could be degraded by the microorganism in the environment when proper conditions such as the sunlight, moisture, oxygen, etc are available (Abe and Doi, 2002). The degradation rate of $\mathrm{P}(3 \mathrm{HB})$ ranges in the order of a few months (in anaerobic sewage) to years (in seawater) (Jendrossek et al.., 1996; Mergaert et al. 1994; Mergaert et al.., 1993). The key factor for their high cost is due to the narrow production to achieve the large economies of the scale. The cost of carbon source, fermentation process and the downstream processing of the polymer contribute to the high cost of manufacturing process of the polymer (Choi and Lee, 1999). About $50 \%$ of the production costs of the polyhodroxyalkanoates (PHA) are added by the cost of carbon source (Halami, 2008). PHA are biodegradable, water insoluble, non-toxic, bio-compatible, piezoelectonic, thermoplastic, and/or elastomeric. These features make them suitable for applications

\footnotetext{
* Author for correspondence: ashokpandey56@yahoo.co.in
} 
in the packaging industry and as substitute for hydrocarbon-based plastics (Anderson and Dawes, 1990). It has wide applications in different areas such as packaging material, long term dosage of drugs, medicines, insecticides, herbicides, fertilizers cosmetic world, disposable items such as razors, utensils, diapers, feminine hygiene products, cosmetics containers, shampoo bottles, cups etc. Studies are progressing for its relevance in medical field for bone replacements and plates, surgical pins, sutures, wound dressings, and blood vessel replacements.

Polyhydroxybutyrate is the intracellular granule, synthesized by bacteria and acts as an energy storage facility. In some Bacillus sp, it supplies energy for sporulation (Slepecky and Law, 1961). The low molecular weight $\mathrm{P}(3 \mathrm{HB})$ is a part of bacterial $\mathrm{Ca}^{2+}$ channels (Lara et al.., 1999). The storage granules are synthesized by the microorganisms when the cell's surroundings contain an unbalanced growth condition such as limited concentration of $\mathrm{O}, \mathrm{N}, \mathrm{P}, \mathrm{S}$, or trace elements, e.g., $\mathrm{Mg}, \mathrm{Ca}, \mathrm{Fe}$ and high carbon concentration (Lee, 1996, Sudesh et al.., 2000; Kessler and Witholt, 2001). Under normal growth conditions, the nutrient sources are used for the synthesis of proteins essential for the growth in bacteria. The nitrogen source depletion leads to the cessation of protein synthesis, which in turn leads to the inhibition of TCA cycle enzymes such as citrate synthase and isocitrate dehydrogenase and consequently slows down the TCA cycle. As a result, the acetyl-CoA routes to $\mathrm{P}(3 \mathrm{HB})$ biosynthesis (Dawes and Senior, 1973). Both the shortening of external nutrients and internal sources such as RNA or enzymes facilitate the PHA synthesis. The aim of this work was to study the production of polyhydroxybutyrate (PHB) using agro- industrial residues as the carbon source.

\section{MATERIALS AND METHODS}

\section{Microorganism and inoculum preparation}

Bacillus sphaericus 5149 was obtained from the NCIM (Pune) and maintained on agar slants and Petri dishes containing Luria Bertani agar media. The primary inoculum was prepared in Luria Bertani medium in $250 \mathrm{ml}$ Erlenmeyer flask containing $50 \mathrm{ml}$ of sterile medium (autoclaved at $121.5^{\circ} \mathrm{C}$ for 15 minutes) and inoculated from the stock culture. After $16 \mathrm{~h}$ incubation at $30^{\circ} \mathrm{C}$ and
$200 \mathrm{rpm}, 2 \mathrm{ml}$ of culture was taken to inoculate the flask containing $100 \mathrm{ml}$ of sterile cultivation medium, which contained $(\mathrm{g} / \mathrm{L}):\left(\mathrm{NH}_{4}\right)_{2} \mathrm{SO}_{4}, 2$; $\mathrm{KH}_{2} \mathrm{PO}_{4}, 2 ; \mathrm{Na}_{2} \mathrm{HPO}_{4}, 0.6 ; \mathrm{MgSO}_{4} .7 \mathrm{H}_{2} \mathrm{O}, 0.2$; Yeast extract, 0.2; Fructose, 10; and $0.1 \mathrm{ml}$ trace element solution. The trace element solution contained (g/L): $\mathrm{H}_{3} \mathrm{BO}_{3}, 0.01 ; \mathrm{MnSO}_{4} \cdot \mathrm{H}_{2} \mathrm{O}, 0.02$;

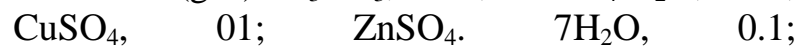
$\left(\mathrm{NH}_{4}\right)_{6} \mathrm{Mo}_{7} \mathrm{O}_{24} .4 \mathrm{H}_{2} \mathrm{O}$, 0.02. Fructose and trace element solution were autoclaved separately and reconstituted prior to the inoculation. The flasks were incubated at $30^{\circ} \mathrm{C}$ and $200 \mathrm{rpm}$ for the requested time.

\section{Growth kinetic studies of the culture}

The above described medium containing fructose as sole carbon source was used for the kinetic studies. Fermentation was carried out as above for $36 \mathrm{~h}$. At regular intervals, the samples were removed (as whole flasks in duplicate) and analyzed the biomass, PHB production, reducing sugars and protein.

\section{Effect of inoculum size and age}

Different inoculum size varying from 1 to $5 \mathrm{ml}$ was tested for the effect of inoculum size on PHB production. Also, the optimization of pre-inoculum age from 12 to $24 \mathrm{~h}$ with an interval of $4 \mathrm{~h}$ was carried out. To find out the number of the cells in the inoculum size, serial dilution of the inoculum was done and plated on Luria-Bertani agar media and the colonies were counted after incubated at $30^{\circ} \mathrm{C}$ for $24 \mathrm{~h}$.

\section{Effect of pH on PHB production}

Different initial $\mathrm{pH}$ of the medium (5.0 to 8.0) was used to check whether $\mathrm{pH}$ has any noticeable effect on PHB production. The initial $\mathrm{pH}$ of the medium was adjusted by $1 \mathrm{~N}$ hydrochloric acid or sodium hydroxide.

\section{Evaluation of agro-industrial residues as substrate}

Seven agro-industrial residues, viz., wheat bran, potato starch, sesame oil cake, groundnut oil cake, cassava powder, jackfruit seed powder and corn flour were assessed for selecting the best substrate for PHB production. These were gelatinized, liquefied and saccharified as described by John et al. (2006). The conditions were: gelatinization at $100^{\circ} \mathrm{C}$ for $15 \mathrm{~min}$, followed by liquefaction with alpha amylase (Novo Termamyl, $5000 \mathrm{IU} / \mathrm{ml}$ ) at $85^{\circ} \mathrm{C}, \mathrm{pH} 5$ for $30 \mathrm{~min}$ and then saccharification 
with glucoamylase (Novo AMG, $2000 \mathrm{IU} / \mathrm{ml}$ ) at $60^{\circ} \mathrm{C}$ for $70 \mathrm{~min}$. The hydrolyzate obtained was filtered through a muslin cloth and the clear hydrolyzate containing reducing sugar was used as the sole carbon source for the PHB production. The reducing sugar in the hydrolyzate was measured using dinitrosalicylic acid (DNS) method (Miller, 1959).

\section{Determination of PHB}

Alkaline digestion: The pellet was collected by centrifugation at $8000 \mathrm{x} \mathrm{g}$ for $20 \mathrm{~min}$ and lyophilized. The lyophilized pellet was digested with $30 \%$ sodium hypochlorite solution at $37^{\circ} \mathrm{C}$ for $20 \mathrm{~min}$. The spectrophotometric assay was done as described by Law and Slepecky (1960). The residue was collected by centrifugation at $8000 \mathrm{x} \mathrm{g}$ for $20 \mathrm{~min}$ and performed a series of washing steps using water, acetone and finally ethanol. The polymer was dissolved in chloroform and kept for complete evaporation. Then $5 \mathrm{ml}$ of concentrated $\mathrm{H}_{2} \mathrm{SO}_{4}$ was added and heated for $40 \mathrm{~min}$ at $100^{\circ} \mathrm{C}$ in a water bath. The resultant crotonic acid was measured at $235 \mathrm{~nm}$ against $\mathrm{H}_{2} \mathrm{SO}_{4}$ as blank in a spectrophotometer (Shimadzu 361A, Japan).

\section{RESULTS AND DISCUSSION}

\section{Growth kinetic studies of the culture}

The kinetic study of growth of the culture was carried out to at $\mathrm{pH} 7$ and the concentration of fructose was $5 \mathrm{mg} / \mathrm{mL}$. The reduction in the reducing sugar was an indicator for the ability of the microorganism to consume fructose as the carbon source. After $16^{\text {th }} \mathrm{h}$, there was a sharp decrease in the concentration of fructose probably due to the starting of log phase where cellular metabolism was in its peak (Fig 1). The protein concentration in the medium was estimated using Lowrey's method (Lowry et al.., 1951), which did not show any organized format. At the initial hour of incubation, the protein concentration was very low, after that the concentration increased. As the incubation time progressed, various enzymes might be synthesized in order to facilitate the cell growth and for other metabolic needs. After $16^{\text {th }} \mathrm{h}$, protein concentration increased and at the same time, there was a decrease in the fructose concentration in the medium. This confirmed that this was the phase in which active metabolism was taking place. From $24^{\text {th }} \mathrm{h}$ again the protein profile increased, possibly due to the start of sporulation in the bacterium.

Fig. 2 shows the biomass and PHB production at particular intervals. The PHB yield and biomass concentration increased until $28^{\text {th }} \mathrm{h}$ of fermentation and were $25 \%$ and $1.1 \mathrm{~g} / \mathrm{L}$, respectively. The rapid drop in cell dry weight (CDW) was due to the cell growth decline phase. The slight decrease in PHB production could be due to the fact that the microorganism could synthesize PHB until the sporulation stage and after that the remaining bacterial cells consume the PHB (Benoit, 1990; Nam and Ryu, 1985). Yilmaz et al.., (2005) reported that some $B$. sphaericus strains were able to synthesize PHB up to $32.55 \%$ (w/v).

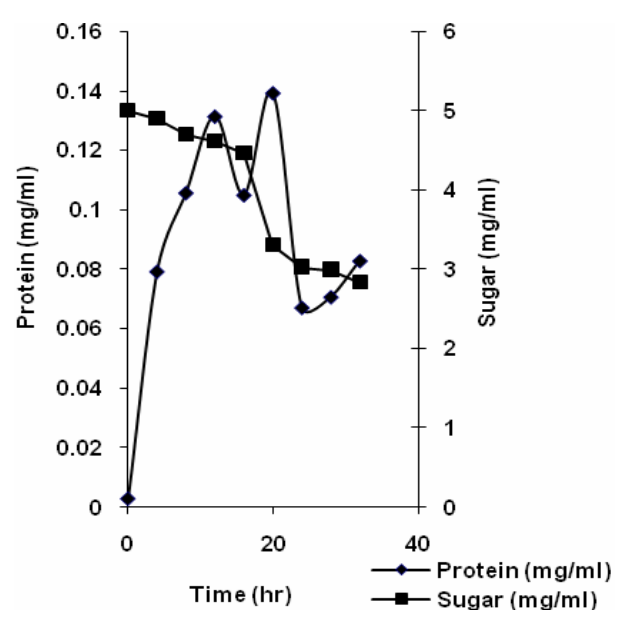

Figure 1 - Residual sugar and protein in the fermentation medium. 


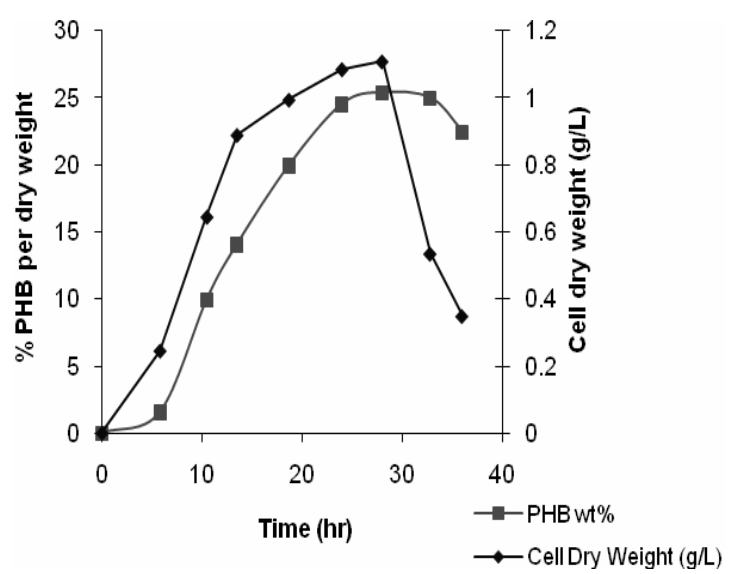

Figure 2 - Content of PHB and dry weight of the B. sphaericus as a function of incubation time

\section{Effect of inoculum age and size}

Pre-inoculum of $16 \mathrm{~h}$ age gave maximum PHB production. The pre-inoculum prepared in the Luria-Bertani medium was rich in nitrogen concentration could involve in protein synthesis in the bacterium and thus increased the biomass. When these cells were put in the production medium, easy assimable carbon source facilitated the growth of mmicroorganism. Maximum production was obtained with $2 \mathrm{ml}$ of preinoculum of $16 \mathrm{~h}$ age, which gave about $25 \%$ PHB (data not shown). The inoculum size of the culture determined was $8 \times 10{ }^{8} \mathrm{CFU} / \mathrm{mL}$.

\section{Effect of $\mathrm{pH}$ on $\mathrm{PHB}$ production}

Change in initial $\mathrm{pH}$ of the medium showed a strong influence on the production of PHB. Even a slight difference in $\mathrm{pH}$ from the optimum point denoted a sudden reduction in PHB production. As shown in the Fig. 3, medium with initial $\mathrm{pH}$ value of 7.5, gave the maximum production of PHB of $25 \%$. The drastic change in production seems to be due to the effect of initial $\mathrm{pH}$ on the bioavailability of trace elements.

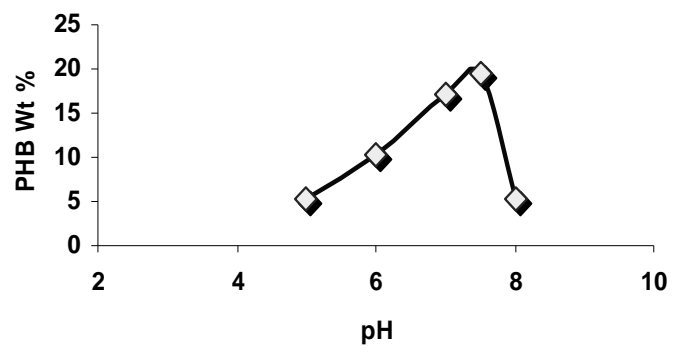

Figure 3 - PHB production by $B$ sphaericus at different initial $\mathrm{pH}$

\section{Evaluation of agro-industrial residues as carbon substrate}

The major restriction in the commercialization of bioplastic is their high production cost. The use of readily available cheap agro-industrial residues as the carbon sources may reduce the higher cost. Several studies have shown the utilization of various carbon sources for different bacterial strains. The glycerol utilization as a carbon source was reported by Taidi et al. for Ralstonia. eutroph (Taidi et al.., 1994). The culture showed no difference in the PHB production in media containing sucrose and glycerol as carbon source. Fatty acids from the fermented fruit and vegetable 
residues also can be supplemented as a carbon source for the microorganisms, to reduce the production cost (Ganzeveld et al.., 1999; Nonato et al.., 2001). There are reports describing $25 \mathrm{~g} / \mathrm{L}$ of PHB when soluble starch was utilized as a carbon source with Azetobacter chroococcum in fedbatch mode (Kim, 2007). PHB production by 11 different Bacillus sp. was studied by Chen et al.. (1991). Results showed a maximum of $50 \%(\mathrm{w} / \mathrm{v})$ PHB of dry cell weight of the bacteria. In one study, 29 Bacillus strains were assessed for PHB production and found that $B$. megaterium showed maximum production of $0.207 \mathrm{~g} / \mathrm{L}$ and productivity percentage of $48.13 \%$. Lowest PHB was $6.53 \%$ in B. subtilis K1 (Aslim et al.., 2002).

Table 1 shows the PHB production in the hydrolyzates of different agro-industrial residues. Van-Thuoc et al.., (2007) reported rgar in order to use the agro-industrial residues as fermentation substrates, these should be subjected to hydrolysis step for the release of easily metabolizable sugars, Acid and enzymatic methods are the two main reported methods for hydrolysis. But acid hydrolysis requires more energy for heating and is relatively difficult to control. It also necessitates corrosion resistant materials since it gives rise to high color and salt and ash content. The enzymatic hydrolysis of sesame oil cake and groundnut oil cake generate only low quantity of reducing sugar and that may be the reason why PHB production became inferior. The enzymatic hydrolysis of sesame oil cake and groundnut oil cake generated only low quantity of reducing sugar that could be the reason why PHB production was inferior from these. Reducing sugar from wheat bran was good and the biomass production was appreciable, but this also showed poor yield of PHB. In a study,
Van-Thuoc et al.., (2007), using wheat bran hydrolyzate as the carbon source, reported the PHB concentration as $1.08 \mathrm{~g} / \mathrm{L}$, which was almost similar to the result of this study $(1.06 \mathrm{~g} / \mathrm{L})$ but the PHB content was $6.8 \%$ in this study in comparison to the reported value of $33.8 \%$ by Van-Thuoc et al.., (2007). The wheat bran hydrolysate is rich in protein concentration (Van-Thuoc et al.., 2007). Although the production medium contained the yeast extract $(0.2 \mathrm{~g} / \mathrm{L})$, the protein in the hydrolyzate might have contributed to the cell growth (CDW $15.5 \mathrm{~g} / \mathrm{L})$. The cassava bagasse hydrolyzate also resulted good growth (CDW $2.5 \mathrm{~g} / \mathrm{L}$ ) but the amount of PHB was low (Table 1). Several agro-industrial residues such as potato starch, babassu, soy cake (Oliveira et al.., 2004) cane molasses, whey (Ahn et al.., 2001) have been reported for PHB production. Fukui and Doi (1998) reported that the plant oils such as olive oil, corn oil and palm were good carbon substrates for $R$. eutropha for PHB production. Thakor et al.. (2005) found the coconut oil as one of the best carbon source for Comamonas testosteroni. Rusendi and John (1995) used waste potato starch hydrolyzate for the production of PHB and reported a yield of $77 \%$ of the biomass dry weight. In the present study, there was only slight difference in PHB production in potato starch and jackfruit seed powder. , However, jackfruit seed powder was selected as the substrate for further studies due to its relative cheaper cost. The reducing sugar obtained by the enzymatic hydrolysis of jackfruit seed powder was $0.1 \mathrm{~g} / \mathrm{mL}$ (data not shown). Bobbio et al.. (1978) reported that jackfruit contained $31.9 \%$ protein, $1.3 \%$ crude lipids and $66.2 \%$ carbohydrates on dry weight basis.

Table 1 - Comparison of synthesis of PHB on hydrolyzates prepared from different agro-industrial residues (2\%)

\begin{tabular}{lccc}
\hline \multicolumn{1}{c}{ Carbon Substrate } & CDW $(\mathbf{g} / \mathbf{L})$ & $\begin{array}{c}\text { PHB Concentration } \\
(\mathbf{g} / \mathbf{L})^{\mathbf{a}}\end{array}$ & $\begin{array}{c}\text { PHB content } \\
(\boldsymbol{\%}))^{\mathbf{b}}\end{array}$ \\
\hline Corn flour & 1.5 & 0.049 & 3.3 \\
Wheat bran & 15.5 & 1.065 & 6.8 \\
Cassava bagasse & 2.5 & 0.161 & 6.4 \\
Jackfruit seed powder & 1.5 & 0.690 & 46.0 \\
Potato starch & 1.5 & 0.710 & 47.0 \\
SOC & 1.0 & 0.146 & 14.6 \\
GOC & 1.5 & 0.280 & 18.7 \\
\hline
\end{tabular}

Gram PHB per liter of culture

${ }^{\mathrm{b}}$ Percentage of PHB in cell dry weight 


\section{CONCLUSION}

From the results it was concluded that the enzyme hydrolyzate of jackfruit seed powder could be used as a good substrate for PHB productions. Maximum production was obtained when a hydrolyzate prepared from $2 \%$ jackfruit seed powder was fermented for $36 \mathrm{~h}$ at $30^{\circ} \mathrm{C}$ in a medium containing nutrient salts and initial $\mathrm{pH}$ as 7.5. The PHB content in the cells was $46 \%$.

\section{ACKNOWLEDGEMENTS}

NVR acknowledges the award of a fellowship by the Council of Scientific and Industrial Research, Government of India, New Delhi, India.

\section{REFERENCES}

Abe, H.; Doi, Y. (2002), Molecular and material design of biodegradable poly(hydroxyl-alkonate)s', in Doi Y and Steinbuchel A, Biopolymers 3b, Polyesters II, Weinheim, Wiley-VCH, 105-132.

Anderson,A.J. and Dawes, E. A. (1990), Occurrence, metabolism, metabolic role and industrial uses of bacterial polyhydroxyalkanoates. Microbiol Rev., 54, 450-472.

Ahn W. S.; Park, S. J and Lee, S. Y. (2001), Production of poly(3-hydroxybutyrate) from whey by cell recycle fed-batch culture of recombinant Escherichia coli. Biotechnol. Lett., 23, 235-240.

Aslim, B.; Yuksekdag Z. N. and Beyatli Y. (2002), Determination of growth quantities of certain Bacillus Species isolated from soil. Turkish electronic journal of biotechnology, special issue, 24-30.

Association of German Plastics Manufacturers (2001), Plastics: Business Data and Charts, VKE Working Group Statistics and Market Research.

Benoit, T. G.; Wilson, G. R.; Baygh,C. L. (1990), Fermentation during growth and sporulation of Bacillus thuringiensis HD-1. Lett. Appl. Microbiol. 10, 15-18.

Bobbio, F. O.; El-Dash A. A,.; Bobbio, P. A. and Rodrigues, L. R. (1978),Isolation and characterization of the physicochemical properties of the starch of jackfruit seeds (Artocarpus heterorphyllus).Cereal Chem 55, 505-11.

Chen, G.Q.; Ko“ nig, K. H. and Lafferty, R. M. (1991), Occurrence of poly-D(-)-3- hydroxyalkanoates in the genus Bacillus. FEMS Microbiol. Lett., 84, 174-176.

Choi, J. and Lee, S. Y. (1999), Factors affecting the economics of polyhydroxyalkanoate production by bacterial fermentation Appl Microbiol Biotechnol., 51, 13-21.

Dawes, E. A. and Senior, P. J. (1973), The role and regulation of energy reserve polymers in microorganisms. Adv. Microbiol. Physiol. 10, 135-266.

Fukui, T. and Doi, Y. (1998), Efficient production of polyhydroxyalkanoates from plant oils by Alcaligenes eutrophus and its recombinant strain. Appl. Microbiol. Biotechnol.49, 333-336.

Halami, P. M. (2008), Production of polyhydroxyalkanoate from starch by the native isolate Bacillus cereus CFR06 World J Microbiol. Biotechnol., 24, 805-812.

Jendrossek, D.; Schirmer, A. and Schlegel, H. G. (1996), Biodegradation of polyhydroxyalkanoic acids. Appl. Microbiol. Biotechnol., 46, 451-463.

Kessler, B. and Witholt, B. (2001), Factors involved in the regulatory network of polyhydroxyalkanoate metabolism. J Biotechnol., 86, 97-104.

Kim, B. S. (2007), Production of PHB from inexpensive substrates. Enzyme Microb. Technol., 27, 774-777.

Lara, L.; Madison. and Huisman, G. W.( 1999), Metabolic Engineering of Poly(3Hydroxyalkanoates): From DNA to Plastic, Microbiol. Mol Biol. Rev., 63, 21-53

Lee, S.Y. (1996), Plastic bacteria? Progress and prospects for polyhydroxyalkanoate production in bacteria. Trends Biotechnol., 14, 431-438.

Lowry, O. H.; Rosenbough, H. I.; Fair, A. L. and

Randall, R. I. (1951), Protein measurement with the Folin phenol reagent. J. Biol. Chem., 193, 265-275.

Mercan, N. and Beyatli, Y. (2001), Production of poly$\beta$-hydroxybutyrate (PHB) by Bacillus sphaericus strains. J. Biotechnol 25, 2, 1-7.

Mergaert, J.; Anderson, C.; Wouters, A. and Swings, J. (1994), Microbial degradation of poly(3hydroxybutyrate) and poly(3-hydroxybutyrate-co-3hydroxyvalerate) in compost. J. Environ. Polym Degrad., 2, 177-183.

Mergaert, J.; Webb, A.; Anderson, C.; Wouters, A. and Swings, J. (1993), Microbial degradation of poly(3hydroxybutyrate) and poly(3-hydroxybutyrate-co-3hydroxyvalerate) in soils, Appl. Microbiol. Environ. Microbiol., 59, 233-3238.

Miller, G. L. (1959), Use of dinitrosalicylic acid reagent for determination of reducing sugar. Anal. Chem. 31, 426-428.

Nam, D. H. and Ryu, D. D. Y. (1985), Relationship between butirosin biosynthesis and sporulation in Bacillus circulans. Antimicrob. Agents Chemother. 27, 789-801.

Nonato, R. V.; Mantelatto, P. E. and Rossell C. E. V. ( 2001), Integrated production of biodegradable plastic, sugar and ethanol, Appl. Microbiol. Biotechnol., 57, $1-5$. 
Oliveira, F. C.; Freire D. M. G. and L.R. Castilho, L. R. (2004), Production of poly(3-hydroxybutyrate) by solid-state fermentation with Ralstonia eutropha Biotechnol. Lett., 26, 1851-1855.

Rusendi, D. and Sheppard, J. D. (1995) Hydrolysis of potato processing waste for the production of poly$\beta$-hydroxybutyrate. Bioresour. Technol., 54, 191196.

Slepecky, R. A. and Law, J. H. (1961), Synthesis and degradation of poly-b-hydroxybutyric acid in connection with sporulation of Bacillus megaterium. J. Bacteriol. 82, 37-42.

Slepecky, R. A. and Law, J. H. (1960), A rapid spectrophotometric assay of $\alpha, \beta$-unsaturated acids and , $\beta$-hydroxy acids. Anal. Chem., 32, 1697-1699.

Sudesh, K.; Abe, H. and Doi, Y. (2000), Synthesis, structure and properties of polyhydroxyalkanoates: biological polyesters. Prog Polym Sci., 25, 15031555.

Taidi, B.; Anderson, A. J.; Dawes, E. A. and Byrome, D. (1994), Effect of carbon source and concentration on the molecular mass of poly(3-hydroxybutyrate) produced by methylobacterium extorquens and
Alcaligenes eutrophus. Appl. Microbiol.Biotechnol. 40, 786-790.

Thakor, N.; Trivedi, U. and Patel, K. C. (2005), Biosynthesis of medium chain length poly(3hydroxyalkanoates) (mcl-PHAs) by Comamonas testosteroni during cultivation on vegetable oils Bioresour. Technol., 96, 1843-1850.

Van- Thuoc, D.; Quillaguaman, J.; Mamo, G. and Mattiasson, B. ( 2007), Utilization of agriculture residues for poly (3-hydroxybutyrate) production by Halomonas boliviensis LC1. J. Appl. Microbiol., 104, 420-428.

Yilmaz1, M.; Soran, H. and Beyatli, Y. (2005), Determination of poly- $b$-hydroxybutyrate (PHB) production by some Bacillus spp. World J. Microbiol. Biotechnol., 21, 565-566.
Received: May 27, 2007; Revised: November 11, 2007; Accepted: October 13, 2008. 